\title{
PENERAPAN GOOD GOVERNANCE TERHADAP PELAYANAN BEA PEROLEHAN HAK ATAS TANAH DAN BANGUNAN DI BADAN PENDAPATAN DAERAH KABUPATEN KUTAI TIMUR
}

Oleh :

\author{
Aswin Tri Astaman ${ }^{1}$ dan Maskan. AF. ${ }^{2}$ \\ ${ }^{1}$ Mahasiswa Fakultas Ilmu Sosial dan Ilmu Politik \\ Universitas 17 Agustus 1945 Samarinda. \\ ${ }^{2}$ Dosen Fakultas Ilmu Sosial dan Ilmu Politik \\ Universitas 17 Agustus 1945 Samarinda.
}

\begin{abstract}
This study intend to determine the extent of the application of the principles of good governance and also know what are the obstacles in the process of applying these principles. This study was implemented in the revenue agency of the East Kutai Regency.

To support the study, a sample of ten people was taken, five people are office employees and five people are taxpayer. The method used in this study is the interview method, then the type of research is descriptive qualitative.

Based on the results of study with a focus on rule of law, transparent, responsive, equity and accountability, conclusions can be drawn. Law enforcement has been implemented quite well and has been carried out accordingly. Services provided by the revenue agency have been carried out directly and openly to the public, The officers in providing services are good enough, it can be seen from the attitude of the officers are quite friendly, helping to complete the lack of copies of community files and other things in providing services, the ongoing service does not differentiate the management of files, all files are processed according to the type of files obtained, and The Office is always responsible for all types of file acquisition in the event of payment errors such as underpayment or overpayment of taxes.

As for the constraints, in accordance with the focus of study there are often misunderstandings of the public regarding applicable regulations, sometimes the officer is not in place when the service is in progress, lack of information regarding the period of completion of the files obtained, and a matter of time if there is an overpayment of tax refunds.
\end{abstract}

Keywords: Application Good Governance, taxpayer, land and building rights fees 


\section{PENDAHULUAN}

\section{A. Latar Belakang}

Dewasa ini, pelaksanaan pembangunan di Indonesia tak luput dari usaha bersama antara pemerintah, masyarakat, lembaga swasta yang bertujuan untuk mengembangkan dan memajukan kesejahteraan masyarakat secara keseluruhan. Dalam menjalankan proses tersebut sangat penting memiliki sikap saling bersinergi dan menopang satu sama lainnya. Dalam menjalin hubungan antara pemerintah dengan masyarakat dan pihak swasta maka pemerintah menerapkan suatu sistem yang bertujuan untuk memenuhi kebutuhan mereka yaitu pelayanan publik.

Secara umum, citra pelayanan publik di Indonesia masih belum sepenuhnya baik di mata masyarakat dikarenakan masih banyaknya hal yang perlu dibenahi, misalnya dari prosedur yang berbelit - belit, waktu penyelesaian yang belum tepat waktu, petugas pelayanan yang kurang ramah, serta tidak professionalnya petugas. Pelayanan publik di Indonesia pun sudah biasa menjadi gambaran sumber korupsi, seperti pungutan liar, keterlambatan petugas hadir di tempat pelayanan, dan juga hal lainnya.

Hal diatas disebutkan bahwa citra pelayanan di Indonesia yang berlangsung belumlah baik, hal itu menunjukan bahwa birokrasi yang berjalan sangatlah kurang optimal, maka pemerintah di Indonesia perlu menerapkan prinsip penting tentang penyelenggaran pemerintahan yaitu good governance (tata kelola pemerintahan yang baik), dalam UU No. 25 Tahun 2009 tentang pelayanan publik, didalamnya mengatur prinsip-prinsip pemerintahan yang baik yang merupakan efektivitas fungsi-fungsi pemerintahan itu sendiri. Hal tersebut diharapkan bisa mengoptimalkan birokrasi di indonesia yang kurang optimal tadi. Beberapa contoh prinsip dari good governance ialah transparansi, responsif, keadilan, efektifitas dan efisiensi.dan lain sebagainya.

Walau sebelumnya dikatakan birokrasi yang berjalan oleh pemerintah di Indonesia masih belum optimal, akan tetapi ada instansi pemerintah yang sudah mulai menerapkan prinsip-prinsip dari good governance tersebut di pusat maupun didaerah yang bertujuan untuk memperbaiki kekurangan yang ada, dimana diharapkan agar dapat mengubah pemerintahan menjadi lebih baik. Salah satu contoh dalam hal efektifitas dan efisiensi ialah pemerintah mulai melakukan sistem pelayanan berbasis online, yang mana dalam sistem tersebut proses pelayanan bisa meminimalisir waktu masyarakat maupun pihak lembaga swasta menuju lokasi pelayanan terkait. Contoh lain dalam hal keadilan, pemerintah tidak boleh membandingkan pengurusan dari pihak pejabat, pengusaha besar dengan masyarakat biasa.

Dari berbagai macam jenis pelayanan publik, pelayanan pajak merupakan salah satu jenis pelayanan yang berperan penting untuk 
meningkatkan pendapatan negara melalui pendapatan asli daerah, dimana hal tersebut diproses agar dapat menjadi anggaran pendapatan dan belanja negara (APBN) dan anggaran pendapatan belanja daerah (APBD) yang digunakan untuk proses pembangunan negara serta pembangunan daerah. Pelayanan pajak dapat dilakukan di Badan Pendapatan Daerah (BAPENDA) atau Kantor Pelayanan Pajak di tiap-tiap provinsi dan kabupaten / kota tergantung jenis pajak yang dibutuhkan.

Pelayanan pajak yang berlangsung di provinsi ada lima macam jenis pajak, yaitu Pajak Kendaraan Bermotor dan Kendaraan di Atas Air, Bea Balik Nama Kendaraan Bermotor, Pajak Bahan Bakar Kendaraan Bermotor, Pajak Pengambilan dan Pemanfaatan Air Bawah Tanah, dan yang terakhir Pajak Rokok. Sedangkan pelayanan pajak yang berlangsung ditingkat kabuptaen / kota ada sebelas macam jenis pajak daerah yang dilaksanakan, diantaranya adalah Pajak Hotel, Pajak Restoran, Pajak Hiburan, Pajak Reklame, Pajak Penerangan Jalan, Pajak Mineral Bukan Logam dan Batuan, Pajak Parkir, Pajak Air Tanah, Pajak Sarang Burung Walet, Pajak Bumi dan Bangunan Sektor Perdesaan dan Perkotaan, dan yang terakhir Bea Perolehan Hak Atas Tanah dan Bangunan.

Pelayanan Pajak yang berlangsung di Kabupaten Kutai Timur sudah berlangsung sejak tahun 1999 yang mana dari usianya pelayanan yang telah dilakukan sudah berlangsung cukup lama. Dari sebelas macam jenis pajak yang berlangsung di Kabuptaen Kutai Timur, Bea Perolehan Hak atas Tanah dan Bangunan (BPHTB) merupakan jenis pajak yang berbeda, karena dalam pengurusan pajak tersebut bertujuan untuk proses kepemilikan suatu objek. Selain hal diatas BPHTB juga merupakan jenis pajak yang sangat berpotensi tinggi untuk meningkatkan pendapatan asli daerah pada Kabupaten Kutai Timur.

Dalam lima tahun terakhir, yakni dari tahun 2014-2018 pendapatan asli daerah untuk jenis BPHTB memiliki realisasi pendapatan yang berubahubah yang bisa dilihat sebagai berikut:

\begin{tabular}{|c|c|c|}
\hline No & Tahun & Realisasi BPHTB \\
\hline 1 & 2014 & Rp. 33.928.155.260,00- \\
\hline 2 & 2015 & Rp. 18.894.781.295,00- \\
\hline 3 & 2016 & Rp. 19.450.929.492,00- \\
\hline 4 & 2017 & Rp. 71.319.835.298,05- \\
\hline 5 & 2018 & Rp. 19.802.962.165,05- \\
\hline
\end{tabular}

Tabel 1.1. Realisasi BPHTB Tahun $2014-2018$ 


\section{B. Permasalahan}

Berdasarkan latar belakang yang dikemukakan diatas, maka dapat ditetapkan permasalahan pokok, yaitu:

1. Bagaimana penerapan good governance terhadap pelayanan Bea Perolehan Hak atas Tanah dan Bangunan di Badan Pendapatan Kabupaten Kutai Timur?

2. Apa saja kendala yang dihadapi dalam proses penerapan good governance terhadap pelayanan Bea Perolehan Hak atas Tanah dan Bangunan di Badan Pendapatan Kabupaten Kutai Timur?

\section{KERANGKA DASAR TEORI}

\section{A. Good Governance}

Kata Good Governance terdiri dari dua kata "good" dan "governance". Good berarti Baik, sedangakan governance itu memiliki beberapa pengertian sendiri yang dirumuskan kedalam beberapa perumusan, misalnya United Nation Development Programme (Badan Usaha Pembangunan PBB) mendefinisikan, bahwa good governance adalah "the exercise of political, economic, and administrative authority a nation's affair at all level" (penerapan kekuasaan politik, ekonomi, dan administratif untuk mengelola urusan suatu bangsa pada semua tingkat). Oleh karena itu "istilah Governance" tidak hanya berarti kepemerintahan sebagai suatu kegiatan, tetapi juga berarti: "pengurusan, pengelolaan, pengarahan, pembinaan, penyelenggaraan dan pemerintahan" (Adi Sujatno, 2007:41).

Good governance memiliki beberapa asas-asas yang terdiri dari 13 butir (Adi Sujatno, 2007:45), yaitu:

1. Asas kepastian hukum (principle of legal security)

2. Asas keseimbangan (princple of proportionality)

3. Asas kesamaan (princple of equality)

4. Asas bertindak cermat (princple of carefullness)

5. Asas motivasi (princple of motivation)

6. Asas jangan mencampuradukkan kewenangan (princple of nonmisuse of competence)

7. Asas permainan yang layak (princple of fair play)

8. Asas keadilan atau kewajaran (princple of reasonableness)

9. Asas menanggapi penghargaan yang wajar (princple of meeting raised expectation)

10. Asas meniadakan akibat-akibat suatu keputusan yang batal (princple of undoing the consequences of an annulled decision)

11. Asa perlindungan atas pandangan hidup pribadi (princple of protecting the personal way of life)

12. Asas kebijakan (sapientia) 
13. Asas penyelenggaraan kepentingan umum (princple of public service)

Saling keterkaitan semua struktur pemerintahan memberikan ruang terbuka tercapainya good governance. Dengan sistem pemerintahan yang presidensial, didukung oleh sistem politik yang demokratis, memberikan peluang dan kesempatan yang sangat besar bagi pemerintah dan masyarakat dalam mencapai tujuan pemerintahan yang baik.

Good governance pada dasarnya adalah suatu konsep yang mengacu kepada proses pencapaian keputusan yang mana dalam pelaksanannya diharapkan dapat dipertanggungjawabkan secara bersama-sama. UNDP, seperti dikutip oleh Sasmita (2011), mengajukan beberapa karakteristik good governance adalah sebagai berikut:

1. Partisipasi (Participation). Setiap warga Negara memiliki partisipasi dalam pengambilan keputusan, secara langsung atau tidak langsung. Partisipasi menjadi kunci keberhasilan masyarakat dalam komunikasi secara konstruktif.

2. Penegakan Hukum (Rule of law). Kerangka hukum harus adil dan dilakanakan tanpa pandang bulu. Hukum harus kuat dan tajam. Hukum tidak boleh melakukan diskriminasi tuntuk kepentingan individu atau kelompok. Hukum harus dijadikan sebagai fundamen penegakannya untuk sebuah keadilan dan kemaslahatan.

3. Transparansi (Transparency). Transparansi untuk keterbukaan informasi. Setiap warga Negara mempunyai hak mengetahui segala bentuk informasi yang menjadi konsumsi publik. Informasi harus diberikan oleh lembaga publik kepada masyarakat dengan berbagai media sebagai bentuk pengawasan dan kontrol dari masyarakat terhadap tindakan dan keputusan penyelenggara Negara.

4. Responsif / Peduli (Responsiveness). Peka terhadap kebutuhan dan kondisi yang ada sebagai bentuk pemberian pelayanan yang baik dan berkualitas. Pemerintah harus responsif terhadap apa yang menjadi kebutuhan masyarakat. Setiap pelayanan sejatinya adalah memenuhi kebutuhan masyarakat.

5. Konsensus Orientasi (Concensus orientation). Good governance menjadi perantara kepentingan yang berbeda untuk memperoleh pilihan yang terbaik bagi kepentingan yang lebih luas, dalam kebijakan maupun prosedur.

6. Keadilan (Equity). Semua warga masyarakat mempunyai kesempatan memperbaiki atau mempertahankan kesejahteraan mereka. Prinsip kesetaraan menciptakan kepercayaan timbal-balik antara pemerintah dan masyarakat melalui penyediaan informasi dan menjamin kemudahan di dalam memperoleh informasi yang akurat dan memadai.

7. Efektifitas dan Efisiensi (Effectiveness and Efficiency). Untuk menunjang prinsip-prinsip yang telah disebutkan di atas, pemerintahan yang baik dan 
bersih juga harus memenuhi kriteria efektif dan efisien yakni berdaya guna dan berhasil-guna. Kriteria efektif biasanya di ukur dengan parameter produk yang dapat menjangkau sebesar-besarnya kepentingan masyarakat dari berbagai kelompok dan lapisan sosial. Agar pemerintahan itu efektif dan efisien, maka para pejabat pemerintahan harus mampu menyusun perencanaan-perencanaan yang sesuai dengan kebutuhan nyata masyarakat, dan disusun secara rasional dan terukur. Dengan perencanaan yang rasional tersebut, maka harapan partisipasi masyarakat akan dapat digerakkan dengan mudah, karena program-program itu menjadi bagian dari kebutuhan mereka. Proses-proses pemerintahan dan lembagalembaga membuahkan hasil sesuai kebutuhan warga masyarakat dan dengan menggunakan sumber-sumber daya yang ada seoptimal mungkin.

8. Akuntabilitas (Accountability). Akuntabilitas adalah pertangungjawaban pejabat publik terhadap masyarakat yang memberinya kewenangan untuk mengurusi kepentingan mereka. Para pengambil keputusan di pemerintah, sektor swasta dan organisasi-organisasi masyarakat bertanggung jawab baik kepada masyarakat maupun kepada lembaga-lembaga yang berkepentingan. Bentuk pertanggungjawaban tersebut berbeda satu dengan lainnya tergantung dari jenis organisasi yang bersangkutan. Instrumen dasar akuntabilitas adalah peraturan perundang-undangan yang ada, dengan komitmen politik akan akuntabilitas maupun mekanisme pertanggungjawaban, sedangkan instrumen-instrumen pendukungnya adalah pedoman tingkah laku dan sistem pemantauan kinerja penyelenggara pemerintahan dan sistem pengawasan dengan sanksi yang jelas dan tegas.

9. Visi Strategis (Strategic Vision). Visi strategis adalah pandanganpandangan strategis untuk menghadapi masa yang akan datang. Para pemimpin dan masyarakat memiliki perspektif yang luas dan jauh ke depan atas tata pemerintahan yang baik dan pembangunan manusia, serta kepekaan akan apa saja yang dibutuhkan untuk mewujudkan perkembangan tersebut.

\section{B. Pelayanan Publik}

Pelayanan publik menurut Hardiyansyah (2011: 12) adalah, "pemberian layanan atau melayani keperluan orang atau masyarakat dan/atau organisasi lain yang mempunyai kepentingan pada organisasi itu, sesuai dengan aturan pokok dan tata cara yang ditentukan dan ditujukan untuk memberikan kepuasan kepada penerima pelayanan".

Menurut Lewis dan Gilman (2005), bahwa pelayanan publik adalah kepercayaan publik. Pelayanan publik dilaksanakan secara bertanggung jawab dan sesuai dengan ketentuan dan peraturan yang ada. Nilai akuntabilitas pelayanan yang diberikan dapat memberikan kepercayaan 
kepada masyarakat tentang pelayanan yang diberikan. Pertanggungjawaban terhadap aspek yang dilayani adalah bagian dari pemenuhan terhadap pelayanan publik untuk menjunjung tinggi kepercayaan kepada masyarakat. Kepercayaan masyarakat yang adalah sebagai dasar untuk mewujudkan tercapainya pemerintahan yang baik.

\section{Bea Perolehan Hak Atas Tanah dan Bangunan (BPHTB)}

Dalam pemungutan pajak dikenal apa yang disebut dengan "Empat Maxim" (Four Maxim). Empat maxim sebetulnya merupakan ajaran yang termuat dalam buku Adam Smith: "An Inqury into the Nature and Causes of the Wealth of Nations." Keempat Maxim tadi dalam Soemarno (2007:5-6) adalah: (1) Keadilan (equity), (2) Kepastian (certainty), (3) Ketepatan (conviency), (4) efesiensi (efficiency). Asas Keadilan menyatakan bahwa pajak harus dibebankan kepada masing-masing subjek pajak sesuai dengan kemampuannya. Negara tidak boleh mengadakan diskriminasi terhadap sesama wajib dan objek pajak. Di samping itu, pajak-pajak yang dibayar haruslah sudah pasti, terutama mengenai subjek, objek, besar, serta waktunya. Kepastian mencegah sikap-sikap kompromistis dan kekaburan. Pemungutan pajak harus dilakukan pada saat yang tepat, terutama bagi pembayarnya. Saat yang tepat adalah saat yang paling dekat dengan diterima/dinikmatinya objek pajak yang bersangkutan. Asas efesiensi mengatakan bahwa pemungutan pajak harus dilakukan seefisien mungkin. Artinya, jangan sampai biaya untuk memungut pajak terlampau besar dibandingkan dengan pajak yang diterima oleh Kas Negara.

Pengertian Pajak Daerah adalah salah satu sumber pendapatan daerah (APBD) yang penting untuk membiayai pelaksanaan pemerintahan daerah dan pembangunan. Pajak Daerah adalah kontribusi wajib kepada daerah yang terutang oleh orang pribadi atau badan yang bersifat memaksa berdasarkan undang-undang dengan tidak mendapatkan imbalan secara langsung dan digunakan untuk keperluan daerah bagi sebesar-besarnya kemakmuran rakyat. Pengertian tersebut termuat di dalam Undang-undang Pajak Daerah dan Retribusi Daerah Nomor 28 Tahun 2009.

Pajak Daerah ditetapkan oleh Pemerintah Daerah dengan Peraturan Daerah (Perda). Wewenang pemungutan pajak dilaksanakan oleh Pemerintah Daerah dan hasilnya digunakan untuk membiayai pengeluaran Pemerintah Daerah dalam penyelenggaraan pemerintah dan pembangunan. Pajak Daerah ini berlaku pada provinsi dan kabupaten atau kota. Pihak atau masyarakat yang melakukan pembayaran pajak tidak akan merasakan manfaat langsung dari Pajak Daerah. Pengalokasian Pajak Daerah digunakan hanya untuk kepentingan umum dan sebesar-besarnya untuk kemakmuran rakyat, seperti pembangunan jalan, jembatan, pembukaan lapangan kerja baru, dan lain-lain. 
Menurut Undang-Undang No. 28 Tahun 2009 Pajak daerah mimiliki 4 macam fungsi, yaitu:

1. Fungsi Anggaran

Pajak Daerah sebagai bagian dari Pendapatan Asli Daerah (PAD) digunakan untuk pendanaan rutin seperti belanja pegawai, belanja barang, pemeliharaan, pembangunan, dan juga sebagai tabungan Pemerintah Daerah.

2. Fungsi Mengatur

Pemerintah Daerah mengatur pertumbuhan ekonomi melalui kebijaksanaan Pajak Daerah. Melalui fungsi ini, dana dari Pajak Daerah dapat digunakan sebagai salah satu alat untuk mencapai tujuan ekonomi pemerintahan dan mengurangi masalah ekonomi. Misalnya, jika pemerintah ingin menarik penanam modal, maka dapat diberikan keringanan pajak pada sektor tertentu. Dengan demikian diharapkan akan ada penyerapan lapangan kerja.

3. Fungsi Stabilitas

Pajak Daerah yang dananya terus ada membantu pemerintah untuk menstabilkan harga barang dan jasa sehingga dapat mengurangi inflasi. Tetapi untuk dapat memenuhi fungsi ini pemungutan dan penggunaan pajak harus dilakukan secara efektif dan efisien.

4. Fungsi Retribusi Pendapatan

Pajak Daerah yang ada digunakan untuk mebiayai semua kepentingan umum termasuk untuk membuka lapangan kerja baru sehingga terjadi pemerataan pendapatan agar kesenjangan ekonomi antara yang kaya dan miskin tidak terlalu menonjol. Pajak Daerah diharapkan dapat meningkatkan pemerataan di setiap daerah karena penyaluran pajak yang baik akan meningkatkan kualitas pembangunan.

Syarat umum pengurusan BPHTB pada Badan Pendapatan Daerah Kabupaten Kutai Timur sesuai dengan Surat Keputusan Bupati ialah sebagai berikut:

1. SPPD BPHTB

2. Fotocopy KTP Wajib Pajak

3. Fotocopy KK Wajib Pajak

4. Fotocopy Profil Perusahaan

5. Fotocopy SPPT PBB yang sudah dibayarkan

6. Fotocopy Bukti Kepemilikan Tanah (Surat Tanah / SK BPN / Sertifikat)

7. Fotocopy Surat Keterangan Waris / Hibah (Jika jenisnya Waris / Hibah)

8. Surat Kuasa jika dikuasakan (Asli). 


\section{Kerangka Pemikiran}

Untuk mengetahui seberapa jauh penerapan good governance pada pelayanan publik, bisa dilakukan dengan metode tanya jawab, kuesioner , dan melihat sendiri kondisi dilokasi secara langsung. Penelitian seperti ini sudah cukup efektif untuk melihat kondisi sebenarnya yang sedang terjadi pada pelayanan publik yang berlangsung.

Adapun kerangka pikir dalam proses penelitian ini dapat digambarkan sebagaiberikut:

Pelayanan Bea Perolehan Hak Atas Tanah dan Bangunan yang berlangsung di Badan Pendapatan Daerah Kabupaten Kutai Timur

1. Penegakan Hukum (Rule of law).

2. Transparansi (Transparency).

3. Responsif / Peduli (Responsiveness)

4. Keadilan (Equity).

5. Akuntabilitas (Accountability).

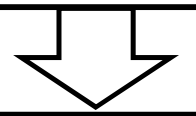

Pelayanan Bea Perolehan Hak Atas Tanah dan Bangunan berkualitas yang menerapkan tata kelola pemerintahan yang baik (Good Governance)

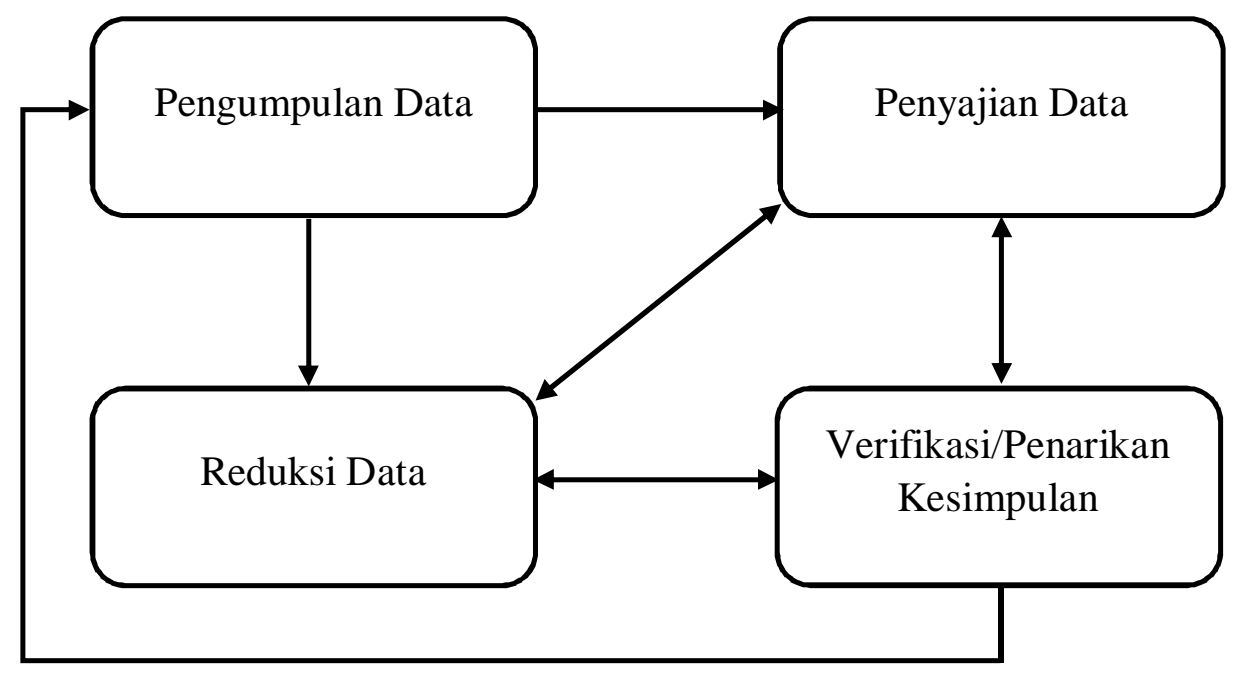




\section{METODE PENELITIAN}

\section{A. Jenis Penelitian}

Penelitian ini merupakan penelitian deskriptif kualitatif. Metode kualitatif adalah metode penelitian yang digunakan untuk menggambarkan fakta serta keterangan-keterangan yang ada di lapangan, sedangkan deskriptif ialah sifat data penelitian kualitatif yang wujud datanya berupa deskripsi objek penelitian yaitu kata-kata, gambar, dan angka-angka yang tidak dihasilkan melalui pengolahan statistika yang ada di obyek penelitian pada Badan Pendapatan Daerah Kabupaten Kutai Timur.

\section{B. Teknik Analisis Data}

Menganalisis data merupakan suatu tahap yang sangat kritis dalam penelitian. Dalam hal ini, mencakup analisis yang memiliki langkah-langkah dalam mengolah informasi, proses penafsiran data, dan penyimpulan hasil penelitian. Dengan jenis penelitian diatas, maka peneliti menggunakan metode penelitian kualitatif menurut Miles dan Huberman. Teknik analisis data kualitatif menurut Miles dan Huberman dapat dijelaskan sebagai berikut:

\section{Pengumpulan Data}

Pengumpulan data ialah data mentah yang dikumpulkan dalam suatu penelitian. Data dikumpulkan di Badan Pendapatan Daerah Kabupaten Kutai Timur.

2. Reduksi Data

Reduksi data diartikan sebagai proses pemilihan, pemusatan perhatian pada penyederhanaan, pengabstrakan, dan transformasi data kasar yang muncul dari catatan-catatan tertulis di lapangan. Reduksi data merupakan suatu bentuk analisis yang menajamkan, menggolongkan, mengarahkan, membuang yang tidak perlu, dan mengorganisasi data dengan cara sedemikian rupa hingga kesimpulan-kesimpulan finalnya dapat ditarik dan diverifikasi. Dengan reduksi data peneliti tidak perlu mengartikannya sebagai kuantifikasi.

3. Penyajian Data

Miles \& Huberman membatasi suatu penyajian sebagai sekumpulan informasi tersusun yang memberi kemungkinan adanya penarikan kesimpulan dan pengambilan tindakan. Mereka meyakini bahwa penyajian-penyajian yang lebih baik merupakan suatu cara yang utama bagi analisis kualitatif yang valid, yang meliputi: berbagai jenis matrik, grafik, jaringan dan bagan. 


\section{Penarikan Kesimpulan}

Penarikan kesimpulan menurut Miles \& Huberman hanyalah sebagian dari satu kegiatan dari konfigurasi yang utuh. Kesimpulan-kesimpulan juga diverifikasi selama penelitian berlangsung. Singkatnya, maknamakna yang muncul dari data yang lain harus diuji kebenarannya, kekokohannya, dan kecocokannya, yakni yang merupakan validitasnya. Kesimpulan akhir tidak hanya terjadi pada waktu proses pengumpulan data saja, akan tetapi perlu diverifikasi agar benar-benar dapat dipertanggung jawabkan.

\section{PEMBAHASAN}

\section{A. Penegakan Hukum (Rule of law )}

Berdasarkan hasil temuan penelitian, dalam proses penegakan hukum mengenai penerapan perundang undangan untuk pelayanan Bea Perolehan Hak Atas Tanah dan Bangunan dan kendalanya di Badan Pendapatan Daerah Kabupaten Kutai Timur, peneliti mendapatkan sepuluh informan hasil wawancara yang mana dalam proses penegakan hukum sudah diterapkan dengan baik pada pelayanan BPHTB di Badan Pendapatan Daerah Kabupaten Kutai Timur, hal tersebut bisa dilihat saat proses pelayanan BPHTB berlangsung, saat wajib pajak melakukan pengurusan berkas semua prosedur dari awal sampai akhir sudah sesuai dengan alur pelayanan yang telah ditetapkan oleh peraturan daerah dan juga baik pengisian nilai objek pajak pun sudah disesuaikan dengan nilai ketetapan pajak yang sebenarnya.

Hal ini sesuai dengan teori good governance pada karakteristik penegakan hukum yang dikutip oleh sasmita yaitu, "Kerangka hukum harus adil dan dilakanakan tanpa pandang bulu. Hal ini menunjukan bahwa penegakan hukum telah ditegakan dan dilaksanakan dengan baik.

\section{B. Transparansi (Transparency).}

Proses transparansi yaitu mengenai keterbukaan dan kendala untuk pelayanan BPHTB yang berlangsung di Badan Pendapatan Daerah Kabupaten Kutai Timur, peneliti mendapatkan sebagian besar hasil wawancara yang mana seluruh informan setuju bahwa mengenai keterbukaan pelayanan sudah terbuka tanpa ada yang perlu ditutup-tutupi. Semua informasi mengenai tata cara perhitungan pajak, yang terdiri dari perhitungan njop (nilai jual objek pajak), npoptkp (nilai perolehan objek pajak tidak kena pajak) dan npopkp (nilai perolehan objek pajak kena pajak) semua dilakukan didepan wajib pajak, bahkan wajib pajak juga bisa mencari informasi perhitungan tersebut melalui media internet, buku pegangan mengenai peraturan baik di perpustakaan maupun tempat penjualan buku terkait. Untuk 
kendala sebenarnya tidak ada, karena memang tidak ada yang disembunyikan dalam proses pelayanan BPHTB".

Hal ini sesuai dengan teori good governance pada karakteristik transparansi yang dikutip oleh sasmita yaitu, "Transparansi untuk keterbukaan informasi. Setiap warga Negara mempunyai hak mengetahui segala bentuk informasi yang menjadi konsumsi publik. Informasi harus diberikan oleh lembaga publik kepada masyarakat dengan berbagai media sebagai bentuk pengawasan dan kontrol dari masyarakat terhadap tindakan dan keputusan penyelenggara Negara”.

\section{Responsif (Responsiveness)}

Berdasarkan hasil temuan penelitian sebagian besar informan berpendapat bahwa sikap petugas dalam memberikan pelayanan kepada wajib pajak sudah cukup baik yang mana salah satu faktor utama ialah karena para petugas sudah mendapatakan bimtek maupun diklat pelayanan Bea Perolehan Hak Atas Tanah dan Bangunan (BPHTB)

Hal diatas sesuai dengan teori good governance pada karakteristik responsif yang dikutip oleh sasmita yaitu, "Peka terhadap kebutuhan dan kondisi yang ada sebagai bentuk pemberian pelayanan yang baik dan berkualitas. Pemerintah harus responsif terhadap apa yang menjadi kebutuhan masyarakat. Setiap pelayanan sejatinya adalah memenuhi kebutuhan masyarakat".

\section{Keadilan (Equity).}

Hasil penelitian, dalam hal keadilan yaitu mengenai apakah dalam pelayanan BPHTB di Badan Pendapatan Daerah Kabupaten Kutai Timur sudah bersifat adil serta tidak membeda-bedakan dalam pengurusan berkas jenis apapun dan apakah ada kendala dalam hal tersebut, peneliti mendapatkan sepuluh sampel informan wawancara dimana seluruh narasumber menyatakan setuju bahwa pengurusan berkas sudah berisfat adil dan tidak membeda bedakan.

Untuk kendala tidak dari pihak kantor lebih berpendapat kepada sering salah faham oleh wajib pajak, mereka berfikir bahwa semua jenis berkas jangka waktu pengerjaan itu sama, tetapi waktu penyelesaian berkas berbeda-beda tergantung dari jenis berkasnya, sedangkan dari pihak wajib pajak merasa tidak ada kendala.

Hal diatas sesuai dengan teori good governance pada karakteristik Keadilan yang dikutip oleh sasmita yaitu, "Semua warga masyarakat mempunyai kesempatan memperbaiki atau mempertahankan kesejahteraan mereka". 


\section{E. Akuntabilitas (Accountability).}

Hasil temuan penelitian tentang akuntabilitas yaitu mengenai apakah pihak pelayanan BPHTB di Kabuptaen Kutai Timur bertanggung jawab untuk setiap pengurusan berkas dari awal sampai akhir pengurusan bahkan hingga terjadi kesalahan perhitungan pajak dan apakah ada kendalanya, peneliti mendapatkan sepuluh informan hasil wawancara yang mana seluruh narasumber menyatakan bahwa dari pihak Badan Pendapatan Daerah Kabupaten Kutai Timur sudah cukup bertanggung jawab dalam setiap jenis pengurusan berkas BPHTB.

Untuk kasus lebih bayar maupun kurang bayar cukup jarang terjadi karena sistem yang diterapkan ialah verifikasi dulu baru dibayarkan walaupun tidak menutup kemungkinan terjadinya hal tersebut. Dari sepuluh sampel narasumber hanya Ibu Lya Putriani dan Ibu Hasnani yang pernah mengalami hal tersebut, mereka mengatakan dari pihak kantor sudah bertanggung jawab untuk dana tersebut hanya menurut Ibu Lya Putriani dalam proses pengembalian dana lebih bayar tersebut cukup memakan waktu yang lumayan lama.

Hal diatas sesuai dengan teori good governance pada karakteristik Akuntabilitas yang dikutip oleh sasmita yaitu, "Akuntabilitas adalah pertangungjawaban pejabat publik terhadap masyarakat yang memberinya kewenangan untuk mengurusi kepentingan mereka. Para pengambil keputusan di pemerintah, sektor swasta dan organisasi-organisasi masyarakat bertanggung jawab baik kepada masyarakat maupun kepada lembagalembaga yang berkepentingan. Bentuk pertanggungjawaban tersebut berbeda satu dengan lainnya tergantung dari jenis organisasi yang bersangkutan".

\section{PENUTUP}

\section{A. Kesimpulan}

1. Penegakan hukum yang berlangsung sudah diterapkan dengan baik dan telah dilaksanakan sebagaimana mestinya, hanya kurangnya wawasan masyarakat terhadap aturan-aturan tersebut yang masih menjadi kendala dalam hal ini yang sering menyebabkan kesalahpahaman masyarakat mengenai peraturan yang berlaku.

2. Pelayanan yang dilakukan pihak Bapenda sudah dilakukan secara langsung dan terbuka terhadap masyarakat, sedangkan kendalanya tidak ditemukan karena memang pelayanan yang telah berlangsung tidak ada yang ditutup-tutupi.

3. Petugas dalam memberikan pelayanan sudah baik, bisa dilihat dari sikap petugas cukup ramah, membantu melengkapi kekurangan salinan berkas masyarakat serta hal lainnya dalam memberikan pelayanan, sedangkan 
untuk kendalanya terkadang petugas tidak berada ditempat saat pelayanan sudah berlangsung.

4. Pelayanan yang berlangsung tidak membeda-bedakan kepengurusan berkas, semua berkas diproses sesuai dengan jenis berkas yang di peroleh, sedangkan untuk kendala dari pihak masyarakat adalah kurangnya informasi mengenai jangka waktu penyelesaian berkas yang diperoleh.

5. Pihak Kantor selalu bertanggung jawab untuk segala jenis perolehan berkas apabila terjadi kesalahan pembayaran seperti kurang bayar pajak atau lebih bayar pajak dan kendala hanya ada dimasalah waktu jika terjadi pengembalian dana lebih bayar.

\section{B. Saran}

1. Memberikan informasi mengenai tata cara pengurusan BPHTB lebih lanjut kepada masyarakat secara lebih luas agar masyarakat yang ingin mengurus BPHTB sudah mengetahui lebih dahulu baik aturan aturan maupun persyaratan yang harus dipersiapkan. Hal ini bisa dilakukan dengan cara memberikan informasi kepada pihak kantor desa agar dari pihak desa bisa menyampaikan kepada para Ketua RT masing masing daerah, atau dengan cara lain seperti memberikan informasi melalui website, media sosial dan lainnya.

2. Memberikan Diklat dan Bimtek untuk petugas seluruh pegawai baik petugas Front Office maupun Back Office, jadi jika terjadi petugas berhalangan hadir bisa digantikan oleh pegawai yang lain.

3. Jika terjadi pengembalian dana lebih bayar, memberikan informasi kepada wajib pajak terkait mengenai alur proses pengembalian dana tersebut sesuai dengan peraturan yang berlaku agar wajib pajak bisa mengerti mengapa hal tersebut cukup memakan waktu dalam proses pengembalian dana tersebut.

\section{DAFTAR PUSTAKA}

Barata, Atep Adya. 2003. Dasar - Dasar Pelayanan Prima, Elex Media Komputindo, Jakarta.

Boediono. 2003. Pelayanan Prima Perpajakan, Rineka Cipta, Jakarta.

Dwiyanto, Agus. 2014. Mewujudkan Good Governance Melalui Pelayanan Publik. Gadjah Mada University Press, Yogyakarta.

Hardiyansyah. 2011. Kualitas Pelayanan Publik. Gava Media, Yogyakarta 
Hayat. 2017. Manajemen Pelayanan Publik, PT. Rajagrafindo Persada, Depok.

Mulyadi, Deddy. Hendriktus T. Geodona., Muhammad Nur Afandi., 2018. Administrasi Publik untuk Pelayanan Publik, Alfabeta, Bandung.

S.R., Soemarno. 2007. Perpajakan Pendekatan Komprehensif, Salemba Empat, Jakarta

Sujatno, Adi. 2007. Moral dan Etika Kepemimpinan, Merupakan landasan ke arah Kepemerintahan yang baik (Good Governance), Team 4AS, Jakarta.

Pasalong, Harbani. 2016. Metode Penelitian Administrasi Publik, Alfabeta, Bandung

\section{Peraturan-Peraturan}

Peraturan Bupati Nomor 1 Tahun 2011 Tentang Pajak Daerah yang mengatur mengenai tata cara pemungutan pajak di daerah.

Peraturan Menteri Pendayagunaan Aparatur Negara Dan Reformasi Birokrasi Republik Indonesia Nomor 15 Tahun 2004 tentang Komponen Standar Pelayanan

Undang-undang Nomor 25 Tahun 2008 Tentang Tata Kelola Pemerintahan yang Baik.

Undang-undang Nomor 28 Tahun 2009 Tentang Pajak Daerah dan Retribusi Daerah yang mengatur kembali mengenai pengelolaan pajak daerah dan retribusi daerah.

\section{Sumber Internet}

Cermati.com, 2016. BPHTB: Pengertian, Dasar Hukum, dan Syarat Mengurusnya. https://www.cermati.com/artikel/bphtb-pengertiandasar-hukum-dan-syarat-mengurusnya (dikases 12 November 2019).

Maulida, Rani, 2018. Pajak Daerah: Pengertian, Ciri-Ciri, Jenis, dan Tarifnya. https://www.online-pajak.com/pajak-daerah (dikases 02 November 2019).

Onlinepajak, 2018. Pengertian Wajib Pajak Berdasarkan UU KUP. https://www.online-pajak.com/pengertian-wajib-pajak (dikases 02 November 2019). 
Upthumas01, 2016. Perbedaan Pajak Daerah dan Pajak Pusat. https://bprd.jakarta.go.id/2016/10/10/pajak-daerah-bukan-pajakpusat/ (diakses 02 November 2019 